Pontifícia UniVERsidade CATÓlicA do RIO DE JANEIRO

\begin{abstract}
O que o mercado busca? Um olhar para os processos seletivos de estagiários em uma empresa de óleo e gás
\end{abstract}

Ricardo Diniz Gimenez

Trabalho de Conclusão de Curso

Centro de ciênCIAS sociaIS - CCS

DePARTAMENTO dE AdMINISTRAÇÃO

Graduação em Administração de Empresas 
Ricardo Diniz Gimenez

\section{O que o mercado busca: Um olhar para os processos seletivos de estagiários em uma empresa de óleo e gás}

Trabalho de Conclusão de Curso

Trabalho de Conclusão de Curso, apresentado ao programa de graduação em Administração da PUC-Rio como requisito parcial para a obtenção do título de graduação em Administração.

Orientador: Renata Georgia Motta Kurtz

Rio de Janeiro, junho de 2017. 
"Aprendi muito aqui em Harvard sobre novas ideias em economia e política, tenho grande expectativa para os avanços que estão sendo feitos nas ciências. Mas o maior avanço da humanidade não está nas suas descobertas, mas em como essas descobertas serão usadas para reduzirem as desigualdades. "

(Bill Gates - Discurso em Harvard) 


\section{Agradecimentos}

A minha orientadora, Renata Georgia Motta Kurtz, por acreditar em meu trabalho. Muito obrigado por ajudar na elaboração deste estudo e pelos inúmeros ensinamentos tais como professora e amiga.

Aos colegas de faculdade, por terem tornado esta jornada mais agradável e prazerosa.

A todos os professores, que certamente contribuíram para o meu desenvolvimento acadêmico e profissional.

Aos funcionários do IAG, sempre prestativos e atenciosos para com todas as necessidades dos alunos de administração.

As pessoas que contribuiram e me motivaram na realizacão deste trabalho, especialmente a Alessandra Castro, Jessica Bastos e Yasmin Coutinho.

Ao meu pai, por tudo em minha vida! 


\section{Resumo}

Gimenez, Ricardo D; Kurtz, Renata . O que o mercado busca? Um olhar para os processos seletivos de estagiários em uma empresa de óleo e gás. Rio de Janeiro, 2016. 47 p. Trabalho de Conclusão de Curso - Departamento de Administração. Pontifícia Universidade Católica do Rio de Janeiro.

O presente estudo buscou identificar quais são as competências valorizadas pelo mercado atual para selecionar estagiários, tendo como base o processo de recrutamento e seleção de uma empresa do setor de óleo e gás. Para tanto, realizouse revisão da literatura do tema, abordando o conceito de competências e suas respectivas dimensões de aplicação. A pesquisa documental e as entrevistas presenciais foram os métodos que forneceram os resultados a serem confrontados com a revisão téorica. Como conclusão, ficou evidente que, atualmente, o diferencial de competitividade é assegurado aos jovens profissionais que transcendem suas competências técnicas, que cada vez mais são visualizadas como requisitos mandatórios, e desenvolvem suas competências humanas. Além disso, há grande tendência de que esses profissionais tenham 0 seu potencial mensurado progressivamente de acordo com os resultados que promovem e com sua entrega, que agregam valor à organização.

Palavras-chave

Competências, Recrutamento, Seleção, Estagiários

\section{Abstract}

Gimenez, Ricardo D; Kurtz, Renata. What the market seeks? A look at the selective processes of interns in an oil and gas company. Rio de Janeiro, 2016. 47 p. Trabalho de Conclusão de Curso - Departamento de Administração. Pontifícia Universidade Católica do Rio de Janeiro.

The present study sought to identify the competencies valued by the current market to select interns, based on the recruitment and selection process of a company in the oil and gas sector. For that, a review of the literature on the subject was carried out, addressing the concept of competencies and their respective dimensions of application. Documentary research and presential interviews were the methods that provided the results to be confronted with the theoretical review. As a conclusion, it became clear that today's competitiveness is assured to young professionals who transcend their technical skills, which are increasingly seen as mandatory requirements, and develop their human skills. In addition, professionals are being increasingly measured by their results and deliveries that add value to the organization. 
Key-words

Skills, Recruitment, Selection, Interns 


\section{Sumário}

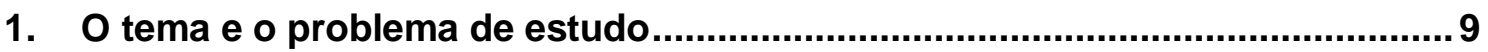

1.1. Introdução ao tema e ao problema de estudo ................................................. 9

1.2. Objetivo do estudo .......................................................................... 10

1.3. Objetivos intermediários do estudo .......................................................... 10

1.4. Delimitação e foco do estudo .............................................................. 10

1.5. Justificativa e relevância do estudo............................................................. 11

2. Revisão de Literatura ................................................................................. 13

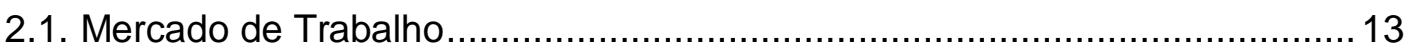

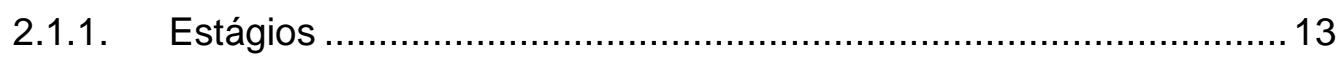

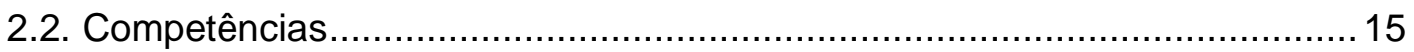

2.2.1. Conceito de Competência ...................................................... 15

2.2.2. Competências Humanas e Técnicas ............................................. 18

2.2.3. Competências Individuais......................................................... 19

2.2.4. Competências Coletivas .......................................................... 20

2.2.5. Competências Organizacionais ................................................ 21

2.3. Gestão por Competências ................................................................. 22

2.3.1. Captação de Competências .................................................23

3. Métodos e procedimentos de coleta e análise de dados do estudo ............... 26

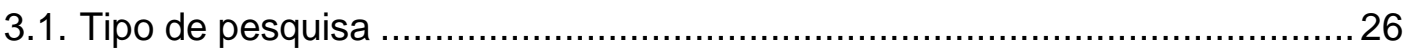

3.2. Procedimentos e instrumentos de coleta de dados utilizados no estudo .......27

3.2.1. Análise documental ................................................................ 27

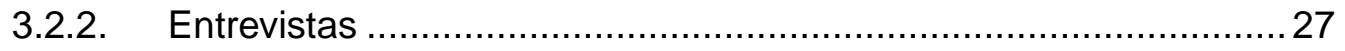

3.3. Formas de tratamento e análise dos dados coletados para o estudo............28

3.4. Limitações do estudo ...................................................................... 29

4. Apresentação e análise dos resultados ........................................................... 30

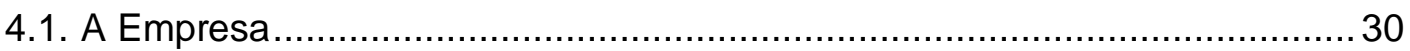

4.2. Descrição e análise dos resultados........................................................... 30

4.2.1. O que a empresa valoriza ....................................................... 30

4.2.2. Conceito de competências ..................................................... 31

4.2.3. Recrutamento e Seleção de estagiários da empresa...................... 32

4.2.4. Técnicas de recrutamento e seleção............................................. 36

4.2.5. Competências para o trabalho: o Programa de Estágio na empresa

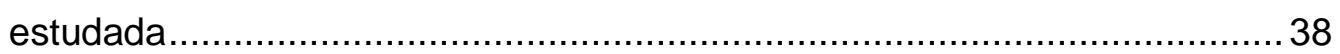

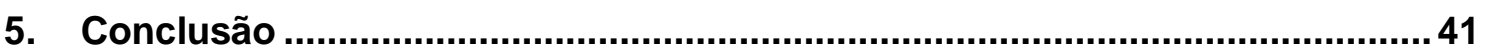




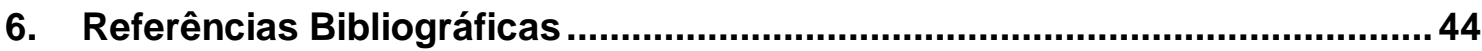

Apêndice 1 - Roteiro de entrevista.......................................................................... 48 


\section{O tema e o problema de estudo}

\subsection{Introdução ao tema e ao problema de estudo}

O advento da revolução industrial e, posteriormente, da revolução técnicocientífica, foi concebido graças ao poder cognitivo do homem, tornando a maximização do desempenho humano, quando o cérebro se sobrepõe à força física, substituindo-a por máquinas e tecnologias diversas, uma das principais preocupações das organizações atuais.

O presente cenário globalizado e neoliberal, de imprescindível competitividade, exige profissionais de qualidade, seja qual for a área de atuação, contexto que aumentou a importância do setor de recursos humanos diante de qualquer organização que almeje sobreviver no complexo mundo empresarial. $A$ área de recrutamento e seleção merece atenção, pois sua grande missão é captar o material humano tão valorizado nos dias de hoje. Com a crescente demanda de profissionais multifacetados e adaptáveis às constantes mudanças no cenário dos negócios $(A B R H$, 2015), há uma notória escassez de capital humano de qualidade. Segundo a Associação Brasileira de Recursos Humanos (2016), 49\% das 200 empresas pesquisadas no segundo semestre de 2015 possuem vagas não preenchidas devido à falta de trabalhadores aptos, fato que torna cada vez mais desafiador recrutar e selecionar os talentos necessários ao desenvolvimento da organização.

A experiência profissional é um dos principais elementos considerados para a contratação de um colaborador pelo $\mathrm{RH}$, tornando o estágio essencial à trajetória da carreira dos jovens, conforme Alba Duarte, diretora da ABRH-RJ. Ela o destaca como uma fase que desenvolve habilidades e atitudes necessárias ao crescimento daquele profissional: os que estagiam precocemente costumam obter vantagens, em detrimento dos concorrentes que o fazem apenas nos últimos semestres da graduação (ABRH-RJ, 2015), porém, de maneira geral, a carência de experiência profissional dos jovens faz das suas competências a principal fonte de diferenciação deles para os demais, constituindo verdadeiro passaporte para o ingresso em uma empresa.

A educação superior é reconhecidamente essencial ao desenvolvimento de qualquer sociedade bem estruturada nos dias atuais, caminho fundamental para profissionais que desejam uma carreira bem-sucedida. Nesse sentido, salienta-se que as instituições de ensino superior (IES) devem preocupar-se ao máximo com a formação de seus alunos, fornecendo as competências necessárias para que o seu corpo discente esteja preparado para entrar no mercado de trabalho. (LACRUZ; 
VILLELA, 2007). As IES devem compreender que as competências técnicoinstrumentais típicas dos currículos dos cursos de graduação já não são suficientes por si só, necessitando-se de uma gama de habilidades pessoais e conhecimentos extracurriculares que assegurarão ao alunado um espaço nas empresas atuais. (VILLELA; NASCIMENTO, 2003). Justamente por isso, Lacruz e Villela (2007) alertam que tais instituições estariam formando profissionais para empresas do passado, que não possuem a dinâmica, a competitividade e a complexidade dos dias atuais, ao invés de focarem em fornecer ao alunado as referidas competências necessárias que fazem a diferença na sua inserção no mercado global contemporâneo.

Para melhor compreender esta temática, o presente trabalho pretende identificar quais as competências requeridas atualmente pelos processos de seleção de estagiários de uma empresa do ramo de óleo e gás do Rio de Janeiro e como se realizam tais processos nesta organização.

\subsection{Objetivo do estudo}

O principal objetivo deste estudo é conhecer quais as competências exigidas dos estagiários pelas empresas, no processo de recrutamento e seleção, identificando como são recrutados e selecionados de fato.

\subsection{Objetivos intermediários do estudo}

Para alcançar o objetivo principal do estudo, deve-se:

- Apresentar as principais competências valorizadas e requeridas pelo mercado de trabalho atualmente conforme a literatura da área;

- Descrever o processo de recrutamento e seleção de estagiários realizado pela empresa estudada;

- Comparar as competências identificadas na literatura com as valorizadas pela empresa estudada na seleção de estagiários;

- Investigar a visão do setor de recursos humanos da empresa estudada a respeito das competências necessárias aos estagiários.

\subsection{Delimitação e foco do estudo}


Apesar dos subsistemas de recursos humanos serem interdependentes, investigou-se apenas como é feito o processo de recrutamento e seleção dos estagiários e quais competências são exigidas e valorizadas neste procedimento. Não se objetiva estudar o recrutamento e seleção de cargos que não sejam voltados ao processo de estágio, tampouco as competências a eles inerentes, bem como não serão alvo deste estudo as competências necessárias e desenvolvidas no futuro deste estagiário após efetivação.

Este trabalho foi realizado em determinada empresa atuante no setor de óleo e gás, localizada na cidade do Rio de Janeiro. As entrevistas aconteceram em outubro de 2016, com profissionais de recursos humanos da empresa, e os documentos analisados fornecidos para a análise foram os mais atualizados possíveis.

\subsection{Justificativa e relevância do estudo}

A complexidade do atual mundo globalizado provoca constante mudança de estratégia das empresas e, consequentemente, das competências por elas requeridas visando à obtenção dos objetivos organizacionais.

O presente estudo faz-se importante à maioria das organizações, que necessita recrutar e selecionar frequentemente talentos que impulsionarão o crescimento empresarial, fortalecendo a cultura organizacional e atendendo com excelência os clientes internos e externos. Melhor dizendo, as empresas precisam identificar as competências inerentes aos negócios na atualidade, selecionando-as, assegurando competitividade a seu grupo, face à dinamicidade de mercado.

Atribui-se relevância acadêmica a este trabalho a partir do momento em que se evidencia a lacuna existente entre o que as Instituições de Ensino Superior oferecem e o que o mercado de trabalho atual efetivamente exige. O relatório do estudo de Souza (2013) a respeito de uma pesquisa feita pela empresa de recrutamento e seleção Hays conclui ser necessário diminuir a diferença entre o que os jovens aprendem na universidade e o que é exigido deles pelo mercado de trabalho.. Assim, quando se trata de requisitos educacionais, o autor aponta para a séria desconexão entre os empregadores, os graduandos e as IES, que acabam fornecendo aos jovens uma qualificação baseada no papel, destituída das habilidades e das experiências exigidas na prática pelo mercado de trabalho (SOUZA, 2013).

Prosseguindo neste viés, este estudo, além de contribuir para o contínuo aprimoramento dos cursos de graduação de ensino superior, atualiza a corrente 
produção textual sobre o tema, servindo como base introdutória a trabalhos posteriores, mediante os diversos direcionamentos que o problema proposto pode seguir. 


\section{Revisão de Literatura}

\subsection{Mercado de Trabalho}

Até o fim da segunda guerra mundial (1945), a maioria das organizações desempenhava atuações locais, porém o avanço tecnológico dos meios de comunicação tornou os países cada vez mais interligados, estreitando laços comerciais e permitindo a tais empresas interagir diariamente e atuar em diversas partes do mundo. Essa conjuntura foi denominada Aldeia Global, termo utilizado pelo filósofo canadense Herbert Marshall McLuhan ao abordar o encurtamento de distâncias, processo de grande impacto nos negócios (MCLUHAN, 2011).

Até a primeira metade do século $X X$, as organizações verificavam apenas a presença das qualificações necessárias para o indivíduo assumir determinado posto de trabalho, requisitos específicos e restritos baseados na noção taylorista/fordista de trabalhador. Tal visão focava apenas no satisfatório desempenho de um cargo especifico (DIAS et al., 2008; DUTRA et al., 2008). Hoje, inseridas num mercado global, estas organizações tem o conhecimento como sendo um recurso essencial ao sucesso, superando o adestramento do profissional para o uso de técnicas e métodos e valorizando aqueles que transformam sua expertise em benefício para os stakeholders internos e externos (VILLELA; NASCIMENTO, 2003).

É por meio da revisão do conceito de qualificação que surge a concepção de competências, cuja origem remete ao impacto que as transformações tecnológicas e estruturais na organização do trabalho exerceram nos negócios e na gestão de pessoas, que passaram a exigir dos profissionais características como flexibilidade, multifuncionalidade e adaptação à mudança (DIAS et al., 2008)

\subsubsection{Estágios}

A procura por adequação, cada vez mais precoce e acirrada nesse mundo globalizado faz com que muitos jovens, a exemplo dos brasileiros, vejam o estágio 
como oportunidade de inserção no mundo profissional, o que muitas vezes se torna obrigatório. Segundo os resultados da pesquisa de Rocha de Oliveira e Piccinini (2011), as principais razões da procura por estágio são a necessidade financeira e o dever social de ingressar na esfera produtiva. Pesquisa realizada em 2015 pela Associação Brasileira de Estágios confirma a competitividade resultante, informando que o maior número de vagas oferecidas se destina a estudantes de Administração $(16,8 \%)$, Direito $(7,3 \%)$, Comunicação Social $(6,2 \%)$, Informática $(5,2 \%)$, Engenharias $(5,1 \%)$ e Pedagogia $(4,2 \%)$, sendo que, dentre os possíveis candidatos (nível superior, médio e técnico), apenas 5,8\% conseguem o estágio, evidenciando a alta concorrência logo nesse início de carreira.

Rocha de Oliveira e Piccinini (2011) analisaram o estudo feito por Domingo (2002) em empresas francesas, explicitando quatro lógicas de compreensão a respeito dos objetivos intrínsecos dos estágios:

1) Inserção profissionalizante, onde permanece a lógica original da criação dos estágios, ou seja, a inserção dos estudantes no âmbito profissional; 2) Período de teste, que avalia possíveis futuros empregados, almejando refinar a seleção conhecendo mais a fundo o aspirante à vaga; 3) Ajuste quantitativo, quando a empresa atende a demanda numérica de trabalhadores por um determinado período (aproximando o estágio de um contrato temporário); 4) Ajuste qualitativo, quando constitui uma espécie de mão-de-obra qualificada e barata.

Considerando a lógica original a justificar o período de estágio, ressalta-se que a busca, por parte dos jovens, é maior por organizações de grande porte, já que o capitalismo estabelecido na maior parte dos países do mundo acaba valorizando-as, segundo as inúmeras reportagens e notícias envolvendo essas instituições, que costumam atuar em nível global. Tal reconhecimento também é difundido por meio da maioria dos cursos de graduação, cujo objetivo, entre outros, é preparar o estudante para o mercado de trabalho. Assim, muitos jovens sonham em ingressar neste tipo de companhia, pois buscam através dela um maior aprendizado e melhores oportunidades de carreira. Apesar disso, nem sempre os estágios em grupos de grande porte correspondem à expectativa da maioria desses jovens, pois muitas vezes o perfil operacional e burocrático das tarefas por eles designadas não está alinhado com o curso de graduação do estudante. Mesmo assim, os jovens permanecem acreditando que um nome desta envergadura Ihes assegurará certificação e competência curricular (ROCHA-DE-OLIVEIRA; PICCININI, 2011). 
Frisa-se a ideia de que um bom estágio seja precedido de processo seletivo rígido (diferencial, em detrimento da maioria dos estágios, que não o fazem), com tarefas complexas e cobrança por resultados e responsabilidades (ROCHA-DEOLIVEIRA; PICCININI, 2011). Tal postura tem sido praticada pelas empresas, que, devido ao crescimento exponencial da procura por estágio nos últimos anos, adotam requisitos de recrutamento e seleção com nível semelhante a aqueles direcionados aos profissionais efetivos (VILLELA; NASCIMENTO, 2003).

O resultado da pesquisa feita por Rocha de Oliveira e Piccinini (2011), procurando identificar quais são as principais competências exigidas pelas empresas durante a seleção de estagiários, mostrou uma valorização de competências não instrumentais, competências humanas, tais como trabalho em equipe, iniciativa, comunicação, foco no resultado, negociação, flexibilidade, orientação para análise, criatividade, relacionamento interpessoal, dentre outras.

Ante 0 exposto, faz-se necessário aprofundar o estudo acerca das características necessárias ao estagiário, devido à crescente valorização que o mercado de trabalho vem conferindo àquelas competências que não transmitidas atualmente nas instituições de ensino.

\subsection{Competências}

\subsubsection{Conceito de Competência}

Brandão (2009) utiliza uma espécie de linha do tempo para exemplificar a evolução do conceito de competência, ainda que em determinada época o nome de referência utilizado não fosse o mesmo da atualidade. Iniciando pelo fim da Idade Média, tal concepção representava o reconhecimento social de que gozava o indivíduo que era dotado da capacidade de argumentar sobre determinado assunto ou de realizar certo trabalho. No início do século passado, o termo já estava alinhado ao âmbito organizacional, demonstrando que determinada pessoa era capaz de desempenhar eficientemente algum papel. Apoiando-se nos princípios taylorista/fordista, tal visão de competência configurava o conjunto de conhecimentos e habilidades que tornavam o trabalhador apto a ocupar um determinado cargo (DUTRA et al., 2008; BRANDÃO, 2009; VILLELA; NASCIMENTO, 2003).

Após a Grande Depressão, em 1929, a Teoria das Relações Humanas ganhou força, principalmente com seu projeto base a "Experiência de Hawthorne", impactando todos os âmbitos empresariais, inclusive o conceito de competência. Este passou a 
considerar não somente conhecimentos e habilidades de seus funcionários, mas também questões sociais e comportamentais. Para Fleury e Fleury (2004), o conceito de competências, que antes era relacionado à definição de requisitos associados ao cargo ocupado, não atendia às demandas por inovação e flexibilidade de um ambiente mutável e globalizado. Esta mudança no mundo dos negócios, portanto, deu origem a uma noção mais ampla, de um conjunto de conhecimentos, de habilidades e de atitudes, tríade mencionada pelos trabalhos de Durand (2000), de Dias et al. (2008), de Dutra et al. (2008) e de Brandão (2009).

Durand (2000), um dos precursores da referida tríade, explica que o conhecimento refere-se às experiências, às informações, aos dados que o indivíduo acumulou na sua vida, a habilidade compreende o famoso "Know-how", ou seja, como desempenhar as atividades a partir do conhecimento que possui, promovendo a ideia de ação, mesmo que abstrata, como um pensamento, e a atitude elenca os aspectos sociais e afetivos do trabalho, como a predisposição de a pessoa a reagir a um estímulo, negativa ou positivamente. Segundo Brandão (2009, p. 12), alguns estudos revelam que estas três dimensões "possuem caráter complementar e interdependente, de forma que existiria uma influência mútua entre eles".

Villela e Nascimento (2007), Dutra et al. (2008) e Brandão (2009) analisam similarmente as correntes teóricas a respeito da noção de competência, dividindo-as em três grupos. A primeira, representada principalmente por McClelland (1973), Boyatzis (1982) e Spencer (1993), dentre outros teóricos, determina que a competência está relacionada à capacidade de realização de determinado trabalho por uma pessoa, ou seja, ao conjunto de conhecimentos, de habilidades e de atitudes que qualificam a pessoa como apta a exercer uma função. A segunda corrente é difundida por autores como Le Boterf (1994; 1999; 2000; 2001), Zarifian (1996; 1999, 2001) e Ruas (2005), que associam a competência não a um conjunto de atributos da pessoa, mas sim à mobilização da capacidade deste indivíduo em um determinado contexto. Por fim, a última e mais recente corrente teórica enfatizam a valorização de sistemas de mensuração e o uso de indicadores para avaliação de desempenho coletivo e individual, como salientam Gonczi (1999), Carbone et al. (2005), Dutra (2000; 2001; 2004), Fleury e Fleury (2000; 2004) e Fleury (2002), referindo-se aos resultados/entrega que o indivíduo oferece ao meio em que se insere.

Ainda que esta tese mais recente não restrinja as competências ao conceito de domínio de capacidades, os resultados da pesquisa de Dutra et al. (2008) acerca da definição de competências humanas no Brasil apontam uma visão ainda antiquada por parte dos profissionais de $\mathrm{RH}$, o que fica claro diante da respectiva proporção de 
respondentes a seguir: 1) Capacidade/Capacitação (58,4\%), em que o conjunto de conhecimentos, de habilidades e de atitudes é o determinante, corroborando a linha americana representada por McClelland (1973), Boyatzis (1982) e Spencer (1993) (58,4\% das respostas); 2) Mobilização de Capacidade (12,6\%), que se refere à mobilização da capacidade da pessoa em determinado contexto, encontrando respaldo nas visões de Le Boterf (1994; 2000; 2001), Zarifian (1996; 2001) e Ruas (2005); 3) Resultados/Entrega (17,6\%), indicando uma agregação de valor ao meio em que a pessoa é inserida, concordando com as abordagens de Dutra (2000; 2001; 2004) Fleury e Fleury (2000) e Fleury (2002); e 4) Outros (11,2\%), que não se enquadram em nenhum referencial teórico apresentado até aqui.

Analisando o resultado da pesquisa, Dutra et al. (2008) demonstram preocupação com a percepção da maioria dos profissionais de $\mathrm{RH}$, que veem a competência como uma qualificação da pessoa ou como a capacidade exigida para determinada posição na empresa. Segundo os mesmos pesquisadores, esta visão taylorista/fordista de gestão de pessoas, que antevê o que o indivíduo deve fazer de acordo com a respectiva descrição de cargo, é arriscada, pois raciocina como se o ambiente organizacional fosse estático, estimulando uma ação de controle por parte da empresa e não de desenvolvimento, ou seja, revestindo de modernismo uma pratica retrógada.

Por tantas correntes teóricas, a aplicação do conceito de competências não aceitaria um tratamento homogêneo, o que diverge da lógica empresarial do pragmatismo e da aplicação, típicos da maioria das práticas gerenciais (DIAS et al., 2008). Sendo assim, com a revisão da literatura a respeito de competências, optou-se por abordar duas classificações. A primeira é a classificação de competências técnicas e humanas, de acordo com o entendimento de Storey (1989). A segunda trata da classificação das competências em três esferas, quais sejam: 1) Competências Individuais e/ou Gerenciais, cuja entrega é resultante do trabalho individual, 2) Competências Coletivas e/ou Grupais, cuja entrega baseia-se no trabalho coletivo, e 3) Competências Organizacionais, as quais dizendo respeito à estratégia da empresa (DIAS et al., 2008)

A seguir, cada categoria será abordada separadamente, sendo importante perceber sua interdependência, como já apontou Brandão (2009). 


\subsubsection{Competências Humanas e Técnicas}

Fleury e Fleury (2004) apontam duas versões estratégicas de recursos humanos baseadas em Storey (1989). Uma delas é a "Soff", que enfatiza aspectos de comunicação, de motivação e de liderança. A outra é a "Hard", que privilegia aspectos quantitativos, de administração racional de recursos humanos, em prol da estratégia do negócio. Segundo a pesquisa dos próprios autores, realizada em empresas do setor de telecomunicações em 2004, a gestão estratégica de recursos humanos nessas empresas parece estar muito mais pautada na versão hard, enfatizando 0 sentido de agregar valor à organização e trabalhando muito pouco as competências em prol dos profissionais em si. A subjetividade do fator humano só começou a ganhar espaço na doutrina a partir do movimento das relações humanas, que passou a constatar que a produtividade de um profissional não se deve unicamente às competências técnicas dele, mas sim que é importante observar todo um contexto sensível humano, imerso em condições sociais e organizacionais, tais como motivação e satisfação no trabalho (HANDEL, 2003).

Procurando indicar qual é a melhor forma de a gestão de $\mathrm{RH}$ proceder, bem como destacar o que os profissionais de $\mathrm{RH}$ devem priorizar para recrutar e selecionar, Storey (1989) desenvolveu as classificações "soft e hard" para competências a serem desempenhadas pelo profissional, conforme mencionado. Estes termos são uma metáfora de associação, onde "hard" tem o sentido de um "recurso", que possui custo, peso monetário, e "soff" é relacionado ao sentido de "humano", alvo de investimento.

Comparadas entre si, essas competências, conhecidas como humanas e técnicas, divergem em pontos importantes. Segundo Storey (1989), a partir da competência humana desenvolve-se uma ótica de trabalho, onde o profissional, por ser altamente qualificado, vence a competitividade acirrada do atual mercado. Desse modo, sua expertise transcende a bagagem de formação da faculdade. Aquele indivíduo assimilou o conteúdo programático do seu curso, indo além, desenvolvendo comportamentos que revelam pró-atividade, eficácia e constante vontade de aprender, qualidades subjetivas que the asseguram um diferencial, em detrimento dos profissionais que somente apresentam a bagagem de formação técnica propriamente dita (STOREY, 1989).

As competências estritamente técnicas, por outro lado, remetem-se ao teor mais objetivo da formação profissional, ao conteúdo programático, configurando habilidades que são as ferramentas primárias à aptidão ao trabalho. As competências técnicas não 
são menos importantes que as humanas, já que são igualmente indispensáveis à inserção do profissional no mercado, mas não constituem um diferencial, visto que se atrelam apenas à formação. O cenário ideal, portanto, é aquele em que elas se complementam, onde o "hard" está presente, com seus recursos, mas o "soff" também é atingido, desenvolvendo a subjetividade que torna aquele colaborador mais produtivo e que permite o seu destaque (STOREY, 1989; HANDEL, 2003).

Segundo Legge (1995), as competências técnicas transmitem a visão clássica acerca do fator humano, que considera o profissional como um passivo fator de produção, meio necessário para concretização dos objetivos da empresa, o que é uma linha de raciocínio que explica a referida associação do termo "hard" à ideia de recurso. Adversamente, as competências humanas remetem-se a profissionais solícitos e proativos, ideia contrária à de simples passivo na produção, uma vez que o "soft" ressalta a colaboração, participação, iniciativa, competências que angariam uma vantagem comparativa a aquele indivíduo no momento de inserção no mercado tão disputado nos dias atuais.

\subsubsection{Competências Individuais}

Uma classificação comum é a que considera a natureza do papel desempenhado pelo indivíduo, caracterizando as competências individuais em técnicas e gerenciais. As competências técnicas são importantes para profissionais que desempenham atividades técnicas, operacionais, dentre outras nessa mesma aptidão. Já as competências gerenciais são exigidas de profissionais que exercem cargos de liderança, seja de uma equipe, de um grupo, de um projeto, ou de um departamento. Essa última categoria de competência chama a atenção dos teóricos pela premissa de que as competências gerenciais do gestor influenciam 0 desempenho de seus subordinados e, consequentemente, os resultados organizacionais (BRANDÃO, 2009).

É comum descreverem-se as competências individuais em forma de pautas ou referenciais de desempenho, possibilitando identificar se uma pessoa detém certa competência por meio da observação de comportamentos específicos (BRANDÃO, 2009). A facilidade de identificar e de observar as competências individuais é um dos motivos para que elas sejam muito utilizadas em processos de gestão, o que será discutido em seção posterior. 
Segundo Fleury e Fleury (2001), a noção de competência individual pode ser associada a expressões verbais, quais sejam: saber agir, mobilizar recursos, integrar 0 saber múltiplo e complexo, saber aprender, saber engajar-se, assumir responsabilidades e ter visão estratégica.

A pesquisa de Sant'anna et al. (2005) elencou quinze competências individuais, reiteradamente apontadas nos trabalhos revisados. São elas: 1) domínio de novos conhecimentos técnicos, associados ao exercício do cargo ou à função ocupada; 2) capacidade de aprender rapidamente novos conceitos e tecnologias; 3) criatividade; 4) capacidade de inovação; 5) capacidade de comunicação; 6) capacidade de relacionamento interpessoal; 7) capacidade de trabalhar em equipes; 8) autocontrole emocional; 9) visão de mundo ampla e global; 10) capacidade de lidar com situações novas e inusitadas; 11) capacidade de lidar com incertezas e ambiguidades; 12) iniciativa de ação e decisão; 13) capacidade de comprometer-se com os objetivos da organização; 14) capacidade de gerar resultados efetivos; 15) capacidade empreendedora.

Os dados obtidos a partir de uma amostra de 654 profissionais do estudo de Sant'anna et al. (2005) revelam elevada percepção dos profissionais, que valorizam competências diretamente associadas a aspectos relacionais e sociais e a fatores de desempenho organizacional. De fato, as que obtiveram maior pontuação na pesquisa foram: a capacidade de gerar resultados efetivos, a capacidade de comprometer-se com os objetivos da organização, a capacidade de trabalhar em equipe, a capacidade de relacionamento interpessoal e a capacidade de comunicação.

\subsubsection{Competências Coletivas}

Estudos na literatura (SANDBERG, 1996; ZARIFIAN, 2001; FROHM; 2002; HANSSON, 2003) mostram que a configuração coletiva se faz presente por meio da dimensão relacional das competências individuais, caracterizando-se pela cooperação, pela interação e pelo compartilhamento do trabalho individual. Esta dinâmica social, que ocupa um espaço intermediário entre o indivíduo e o coletivo, é um ponto crítico inicial para o devido entendimento das competências coletivas (DA SILVA; RUAS, 2016).

Pela obra de Da Silva e Ruas (2016), o conceito de competência coletiva é definido como a capacidade de realizar atividades de uma maneira coletiva, as quais não poderiam ser realizadas de maneira individual. Retour e Krohmer (2011) afirmam 
que a formação das competências coletivas se dá essencialmente pelas experiências adquiridas com a inserção do individuo em determinado grupo. Esses autores ainda afirmam que a cooperação desenvolve uma maneira única de agir por parte de seus componentes, que pode ficar tão enraizada nesses sujeitos ao ponto de, mesmo após a sua separação do grupo, eles manterem aquela característica grupal.

Nesse segmento, os autores mencionados acima destacam a existência de quatro principais atributos presentes no desenvolvimento das competências coletivas, a saber: o referencial comum, que estrutura a ação coletiva, orientando a comunicação entre as pessoas do grupo; a linguagem compartilhada, como sendo o vocabulário comum utilizado no trabalho, que reside na comunicação cognitiva (gestos, olhares, poucas palavras); a memória coletiva, que se refere às aprendizagens coletivas passadas e orienta as posteriores; e o engajamento subjetivo, que simboliza a mobilização subjetiva das pessoas em prol dos objetivos organizacionais.

\subsubsection{Competências Organizacionais}

Para Dias et al. (2008), as competências organizacionais consistem no alinhamento de competências com a estratégia da empresa. Viabilizando o sucesso deste, figuram duas interações: a interação estratégica, que se baseia na adaptação e na definição do portfólio de competências organizacionais da estratégia, com a finalidade de sustentação, e a interação operacional, que estaria situada entre as competências voltadas para estratégia da empresa e as competências coletivas, ou seja, a interação do dia-a-dia.

A primeira interação é de entendimento relativamente simples: são escolhidas as competências, denominadas, por muitos autores, como essenciais, a partir do direcionamento estratégico da empresa. A segunda interação é mais complexa, onde as competências organizacionais seriam firmspecific, ou seja, específicas do contexto, das características e da cultura de cada empresa, portanto dificilmente transferíveis de uma organização à outra. (DIAS et al., 2008)

Segundo Fleury e Fleury (2004), o conceito de competência organizacional enraíza-se na abordagem que concebe a organização como um portfólio de recursos visão baseada em recursos (Resouce Based View - RBV). Este modelo pressupõe que cada organização possui uma coleção de originais recursos e capacidades, que, por sua vez, são a base da estratégia da empresa e de sua capacidade de ganhar retornos acima da média (HITT et al., 1999). Conforme a RBV, Prahalad e Hamel 
(1990) defendem a competência como sendo um atributo da organização que a permite funcionar e alcançar seus objetivos por meio dos recursos internos.

Hitt et al. (1999) citam o termo competências essenciais (core competencies), geralmente tido sob o escopo de uma função organizacional, afirmando tratar-se de capacidades que conferem a vantagem competitiva de uma empresa em detrimento das outras, a exemplo da inovação buscada pelo setor de Pesquisa e Desenvolvimento da Apple.

Portanto, as competências organizacionais classificam-se como básicas ou como essenciais. As primeiras, apesar de não fornecerem vantagem competitiva, se fazem necessárias ao funcionamento da empresa, e as últimas são as que diferenciam uma organização das outras, pois possuem característica de difícil imitação pela concorrência, constituindo uma vantagem concorrencial (PRAHALAD; HAMEL, 1990; BRANDÃO, 2009).

\subsection{Gestão por Competências}

Para Dias et al. (2008), o conceito de gestão por competências ainda não é unânime nas empresas, sendo o centro de todo o sistema de gestão em algumas vezes, ou apenas mais um instrumento para gerir pessoas em outras.

A gestão por competências orienta esforços para planejar, captar, desenvolver e avaliar, nos diferentes níveis da organização - individual, grupal e organizacional -, as competências necessárias à concretização de seus objetivos. Baseada no conceito de que alguns recursos são de extrema importância ao desempenho de uma organização, ela integra e orienta esforços a fim de desenvolver as competências consideradas fundamentais ao alcance das metas organizacionais (BRANDÃO; BAHRY, 2005; BRANDÃO, 2009).

Na parte de diagnóstico de competências, o mapeamento visa identificar o gap existente entre as competências necessárias para alcançar os objetivos organizacionais e aquelas competências internas já disponíveis na empresa. O dinamismo do mercado e a necessidade organizacional de formular novas estratégias para lidar com as contingências tornam obsoletas algumas das competências internas, ou exigem o desenvolvimento de novas, fazendo com que seja necessário um mapeamento periódico (BRANDÃO, 2009). 
Diante disto, o papel da gestão de pessoas é complexo e conflitante. Por um lado, a área de recursos humanos deve comprometer-se com a estratégia da organização, na medida em que atrai, mantém e desenvolve as competências necessárias à realização dos objetivos organizacionais. Por outro lado, este setor deve garantir que haja a agregação de valor ao indivíduo por meio deste processo. Mais um desafio é solucionar o hiato entre a valorização teórica das competências coletivas e a realidade nas organizações, que sentem a carência de procedimentos e de instrumentos que lidem com a concepção das configurações coletivas de modo a utilizá-las de fato nas práticas de gestão, conforme Da Silva e Ruas (2016). Diante desta problemática, a área de $\mathrm{RH}$ vem ganhando espaço, liderando as decisões estratégicas e investindo em definição de novas políticas e práticas de gestão (FLEURY; FLEURY, 2004).

\subsubsection{Captação de Competências}

Em se tratando de captação por competências, foco desse estudo, salienta-se que, uma vez que a seleção por competências cria um perfil para cada cargo, o mapeamento norteia os profissionais de recursos humanos em relação ao que buscar em seus candidatos, tendo em vista as estratégias de competitividade da empresa (BRASIL, 2012; GONÇALVES, 2012). Draganidis e Mentzas (2006) afirmam que tal abordagem viabiliza identificar as habilidades, os conhecimentos e as atitudes necessários a suprir atuais e futuras demandas de seleção de pessoal, respeitando as prioridades organizacionais.

Para tanto, Brandão e Bahry (2005) afirmam dever-se optar pela forma de comportamentos objetivos, verdadeiros referenciais de desempenho e passíveis de observação no trabalho, assegurando clareza, o que evita interpretações diferentes em prol de uma única competência (BRANDÃO; BAHRY, 2005; CARBONE et al., 2005). Talvez esse seja um dos motivos por que as competências coletivas não possuem grande utilização nos modelos de gestão de competências atuais.

O recrutamento determina o perfil de candidatos que participarão da seleção, geralmente feito pelo departamento de recursos humanos da empresa ou pela consultoria especializada. Tal processo envolve a definição das necessidades de contratação e seus requisitos, além da divulgação das mesmas por canais de recrutamento. Após a publicação da vaga, inicia-se a triagem curricular, quando são identificados os perfis que atendem aos requisitos necessários ao cargo. Após esta 
etapa, ocorre o primeiro contato com o aspirante à vaga e, confirmando o seu interesse, checam-se por fim as informações necessárias para convidá-lo à próxima etapa (ABRAPP, 2015; LIMONGI-FRANÇA; ARELLANO, 2002).

Segundo Limongi-França e Arellano (2002), após o recrutamento começa a fase de seleção do candidato mais adequado. Para Tripathi e Agrawal (2014), o propósito da seleção por competências é estabelecer "comportamentos" necessários a um trabalho em particular e verificar a presença dos mesmos nos diferentes candidatos. Segundo estes autores, fazer o alinhamento entre competências dos empregados e as necessidades do cargo gera melhorias no desempenho do indivíduo e da organização como um todo, além de favorecer o aumento da satisfação no trabalho.

Para Brasil (2012), um dos aspectos fundamentais da seleção por competências é a objetividade, já que este método visa à observação de fatos concretos e mensuráveis, tal como o comportamento. Algumas técnicas de seleção procuram avaliar especificamente as competências do candidato, sendo uma delas a entrevista comportamental, estruturada para investigar o comportamento passado da pessoa em um contexto em que a presença ou ausência da competência possa ser identificada (BRASIL, 2012). Este tipo de entrevista permite, a partir da avaliação de uma competência demonstrada em uma situação passada, supor qual será o comportamento do candidato em determinada situação futura (SORANO, 2009). Uma segunda alternativa são os jogos com foco em competências, que permitem ao entrevistador observar os comportamentos do candidato em situações preestabelecidas de modo estratégico (BRASIL, 2012).

Outras técnicas de seleção bastante utilizadas pelas empresas não abordam diretamente as competências. Dentre elas, podem-se citar as entrevistas tradicionais, fundamentais ao processo já que possibilitam conhecer o candidato mais a fundo, tanto em relação às questões pessoais, quanto às profissionais, e as provas de conhecimento ou situacionais, que avaliam conhecimentos gerais ou específicos sobre a área de atuação da vaga e procuram simular situações compatíveis com as que o ocupante do cargo irá vivenciar caso aprovado, respectivamente. No mesmo contexto, também é válido citar os testes psicológicos, que procuram definir os traços de personalidade do candidato, verificando se são compatíveis com o que a organização procura, e as dinâmicas de grupo, que permitem identificar comportamentos como liderança, interação social e em equipe, dinamismo, comunicação e cooperação (ABRAPP, 2015). 
Pelo caráter prático da seleção por competências, por sua capacidade de mensuração das habilidades dos candidatos e por ser bastante assertivo e objetivo, este método apresenta grandes chances de ser eficaz na seleção de talentos (BRASIL, 2012; GONÇALVES, 2012). 


\section{Métodos e procedimentos de coleta e análise de dados do estudo}

Neste capítulo, será descrito o método de pesquisa, os procedimentos e os instrumentos utilizados na coleta de dados, a forma de tratamento e análise dos dados coletados, bem como as limitações do estudo.

\subsection{Tipo de pesquisa}

Realizou-se um estudo qualitativo sobre as atividades de seleção de estagiários da empresa, investigando como a área de $\mathrm{RH}$ planeja e executa a seleção das competências exigidas aos estagiários pelos seus clientes internos.

Para classificá-lo, considerou-se a taxionomia proposta por Vergara (2005), contemplando dois critérios básicos: quanto aos fins e quanto aos meios. Quanto aos fins, a pesquisa caracteriza-se como exploratória, expondo o problema e tendo como objetivo o aprimoramento de ideias ou a descoberta de intuições (GIL, 2002). Quanto aos meios, caracteriza-se a pesquisa como de campo e documental, o que configura um estudo de caso. Segundo Vergara (2005), pesquisa de campo é uma investigação empírica, realizada no local da ocorrência do fenômeno ou em ambiente que disponha de elementos para explicá-lo. Já a pesquisa documental realiza investigação em documentos de qualquer natureza, de órgãos públicos ou privados.

Justificando-se o uso desses métodos, faz-se nova alusão a GIL (2002), pois o autor enfatiza que o resultado de uma pesquisa de campo é mais fiel à realidade, se comparado com resultados oriundos de outros métodos. Ele explica que isso acontece justamente por ela ser desenvolvida no local da ocorrência do fenômeno, viabilizando maior nível de participação ao pesquisador e conferindo maior segurança à resposta dos entrevistados.

De fato, tais premissas acompanham o propósito do estudo de caso, pois buscam compreender o fenômeno social de modo integral, preservando a relação explícita com o cenário em que este é desenvolvido, contexto no qual está imersa a seleção de competências, alvo deste estudo. O estudo de caso é uma das 
metodologias de pesquisa frequentemente utilizadas em investigação qualitativa, generalizando proposições teóricas, contudo mantendo o objetivo de não generalizar os universos (YIN, 2005).

\subsection{Procedimentos e instrumentos de coleta de dados utilizados no estudo}

\subsubsection{Análise documental}

Analisou-se a documentação fornecida pela empresa, conjuntamente com entrevistas com profissionais do setor de $\mathrm{RH}$ desta organização, selecionados por tipicidade e acessibilidade. Os documentos observados foram os seguintes: [1] $O$ procedimento de recrutamento e de seleção de pessoal; [2] a descrição do programa de estágio; [3] a requisição de pessoal; [4] o formulário de descrição de cargo; [5] a avaliação semestral de estágio direcionada para o gestor e para o estagiário; [6] a descrição das competências tranversais de idiomas e informática; [7] a descrição das competências funcionais que são especificas de cada setor da empresas e [8] a descrição das competências organizacionais básicas para o funcionamento da empresa que são utilizadas como parâmetro para o processo de avaliação de desempenho.

\subsubsection{Entrevistas}

Considerando-se a estrutura organizacional da empresa e as limitações de tempo e de recursos para realização desta pesquisa, foram entrevistados os quatro profissionais de recursos humanos responsáveis pelo processo de recrutamento e seleção de estagiários, ou nele envolvidos.

A primeira entrevistada é a gerente corporativa da área, que realiza a gestão de recursos humanos como um todo, incluindo o processo de recrutamento e de seleção de estagiários, objeto do presente estudo. A segunda entrevistada é a coordenadora de recursos humanos, que supervisiona e propõe políticas, práticas e melhorias para a área. A terceira entrevistada é a analista sênior de recursos humanos, responsável 
pelo recrutamento e seleção do pessoal corporativo. A quarta entrevistada é estagiária, que desempenha principalmente a função de auxiliar a analista sênior (terceira entrevistada) no processo de recrutamento e seleção de colaboradores corporativos.

Todas as entrevistas foram presenciais, gravadas e transcritas para a devida análise e validação do entrevistado. Sobre o instrumento de coleta de dados, ressaltase que é um procedimento por meio do qual entrevistador e entrevistados trocam informações oralmente, caracterizando-se como informal, focalizado ou pautado. Para o autor, a caracterização mais pertinente é a de entrevista pautada, em face da qual são agendados vários pontos a serem explorados com o entrevistado, sob o intuito de proporcionar maior profundidade em conhecê-lo (VERGARA, 2005).

O roteiro das entrevistas buscou compreender o que faz um indivíduo ser considerado um bom candidato e identificar o que a empresa valoriza em um estagiário, bem como concluir se há o planejamento de efetivá-lo. Os questionamentos procuraram levantar a percepção das entrevistadas quanto aos conceitos de competência e de planejamento de recrutamento e seleção, bem como quanto às técnicas utilizadas pela instituição ao realizá-lo, o que é devidamente constatado pela leitura do roteiro, disposto no Apêndice 1.

\subsection{Formas de tratamento e análise dos dados coletados para o estudo}

Os dados fornecidos pelas entrevistas e pesquisa documental foram confrontados com o referencial teórico apresentado no segundo capitulo do presente.

Como metodologia de interpretação, utilizou-se a análise de conteúdo, caracterizada pela hermenêutica, de inferências e deduções lógicas, e pelas categorias semânticas, de procedimentos sistemáticos e objetivos de descrição do conteúdo (VERGARA, 2005). Tal método possibilitou a extração de informações a partir das mensagens transmitidas pelo contexto, ao analisar a relação que simples palavras, conceitos e dados mantém entre si. Esta análise é, portanto, de esfera qualitativa e a esse procedimento atribui-se o nome categorização.

Bardin (1988) aborda a categorização e o uso da analogia, afirmando que ambos são métodos consecutivos, que acabam configurando uma só metodologia. Assim, a referida autora descreve a classificação dos elementos alvo de um estudo como 
verdadeiras categorias, de modo que irá reagrupá-los, posteriormente, de acordo com as características que forem análogas a cada um deles (fatores de reagrupamento).

\subsection{Limitações do estudo}

Foram identificados alguns fatores que constituem limitações do estudo realizado. Ainda assim, o método utilizado foi escolhido justamente por ser considerado o mais apropriado a alcançar o objetivo final da pesquisa.

É importante fazer a ressalva de que este estudo foi realizado apenas com uma empresa, logo os resultados obtidos não podem ser generalizados, uma vez que diferentes organizações podem aplicar distintos processos de recrutamento e de seleção e buscar competências também distintas daquelas almejadas pela organização estudada.

A construção do roteiro e a condução da entrevista buscaram preservar ao máximo a veracidade das informações, porém há o risco de o entrevistado não responder os questionamentos com sinceridade, com receio de comprometer de alguma forma a integridade profissional própria ou alheia.

Por fim, como é característica das pesquisas qualitativas analisadas pelo método apresentado na seção anterior, grande parcela do resultado decorre do julgamento e da habilidade do pesquisador de decifrar as informações obtidas e de apresentá-las de modo claro e coeso. 


\section{Apresentação e análise dos resultados}

\subsection{A Empresa}

A empresa, que é palco da presente pesquisa, atua no setor de óleo e gás, em serviços de perfuração de poços de petróleo, tanto onshore, quanto offshore. Fundada na década de 80 , quando a indústria brasileira de óleo e gás florescia, aproveitou o bom momento do setor e conseguiu tornar-se uma das líderes do seu ramo de atuação.

Atualmente, conta com cerca de dois mil e quinhentos colaboradores, distribuídos entre a matriz, situada no Rio de Janeiro, e duas filiais pelo Brasil. No ano de 2016, manteve 32 estagiários, sendo a maior parte desses colaboradores atuantes na matriz.

\subsection{Descrição e análise dos resultados}

\subsubsection{O que a empresa valoriza}

Segundo as entrevistadas, a vontade de aprender e a pró-atividade são os elementos mais valorosos a serem apresentados, não só pelos estagiários, mas também pelos profissionais mais experientes. O profissional jovem, que demonstra gana em desenvolver suas competências técnicas e comportamentais, revela dois dos pontos cruciais a um frutífero início de carreira: humildade e comprometimento, como dispõe a coordenadora de $\mathrm{RH}$ da empresa.

Concordando com este pensamento, a gerente corporativa da empresa frisa outras competências que também são fundamentais, tais como: a facilidade de adaptação e de resolução de divergências, a orientação para entrega de resultado de qualidade em tempo reduzido, o bom relacionamento para com os colegas de trabalho, sobretudo quando se trata do trabalho em equipe, apresentando senso colaborativo e iniciativa. A entrevistada destaca ainda o dinamismo, a boa 
comunicação verbal e escrita e assevera que o indivíduo deve ter a postura profissional sempre em mente, devendo alinhá-la à cultura e aos valores da empresa.

A coordenadora de $\mathrm{RH}$ complementa o raciocínio, afirmando ser vital que aquele colaborador vista a camisa da organização e busque, com afinco, atingir os objetivos e metas por ela traçados. Esta conduta deixará claro que ele não foi atraído exclusivamente pela remuneração e benefícios, mas sim demonstrará sua identificação para com ela e entusiasmo em fazer parte da equipe, conclui a profissional.

Utilizando a ótica de divisão das competências de Dias et al. (2008), pôde-se depreender, da fala desta entrevistada, alguns elementos inerentes às competências coletivas, como o desempenho de trabalho em equipe e o senso colaborativo, destacando-se a importância da interação e cooperação entre os colaboradores e configurando, assim, a dinâmica social explicitada por Da Silva e Ruas (2016). Entretanto, a maioria das competências ressaltadas nas entrevistas são de natureza individual, muitas delas explicitadas pela pesquisa de Sant'anna et al. (2005), que elencou quinze competências individuais, reiteradamente apontadas nos trabalhos sobre o termo. Pela ótica de Storey (1989), pode-se concluir que o discurso das profissionais de $\mathrm{RH}$ da empresa coloca as competências humanas e a versão "soft" da estratégia de recursos humanos, a qual Fleury e Fleury (2004) se referem, em patamar de dominância em relação às competências técnicas.

\subsubsection{Conceito de competências}

Ao serem entrevistadas, as profissionais da empresa em questão afirmaram que o conceito de competências tem grande amplitude, enfatizando que ele remete às qualificações necessárias ao bom desempenho da função e salientando a importância de o mesmo ser estudado por meio de uma perspectiva variada. Desta forma, explicam que ele deverá considerar a tríade de conhecimentos, de habilidades e de atitudes atrelada à capacidade de aquele profissional entregar resultado adequadamente, concluindo que quanto mais eficiente e eficaz for a entrega, mais competente o profissional será considerado. A coordenadora complementa o raciocínio, afirmando que sem a cotidiana e tácita mensuração dessas entregas, utilizadas em processos relativos ao $\mathrm{RH}$, a exemplo do plano de metas e da avaliação de desempenho, seria difícil gerir por competências. Concordando com este pensamento, a analista de $\mathrm{RH}$ comenta que é preciso ter o conhecimento teórico 
pertinente à área de formação, a habilidade para fazer as coisas acontecerem, desempenhando as funções do cargo, o que revela o conhecimento na prática e atitude no momento da execução das tarefas, o que se traduz em pró-atividade. Assim, os resultados demonstram que tais premissas são as responsáveis por gerar o resultado e agregar valor à empresa, o que ratifica a tese de Villela e Nascimento (2003), valorizadores da transformação da expertise em benefício aos stakeholders internos e externos.

Como mencionado no parágrafo anterior, as entrevistadas abordaram a tríade de conhecimentos, de habilidades e de atitudes, presente nas obras de Durand (2000), Dias et al. (2008), Dutra et al. (2008) e Brandão (2009). Apesar de em alguns pontos da entrevista o conceito de competência ainda estar mesclado com várias definições, o discurso do $\mathrm{RH}$ permite inferir que a empresa trata as competências de um modo que a aproxima da corrente teórica mais recente, valorizando um sistema de mensuração que esteja atrelado às competências e que toma como base os resultados que o indivíduo fornece ao meio em que é inserido (Dutra et al., 2008).

\subsubsection{Recrutamento e Seleção de estagiários da empresa}

Segundo a coordenadora de $\mathrm{RH}$, os responsáveis por recrutamento e seleção na empresa tomam o orçamento de pessoal como um norte, já que a área de remuneração anualmente designa, em meados de outubro, os respectivos valores orçados de cada área para que sejam consultados durante o seu planejamento. A partir de então, tem início a análise de quantos profissionais serão alocados em cada setor, bem como os trâmites a serem executados.

Consultando o manual de recrutamento e seleção da empresa, identificou-se como marco inicial o preenchimento do formulário de requisição de pessoal pelo gestor da área, ou pelo $\mathrm{RH}$, quanto a uma vaga determinada. Uma vez aprovada a nova posição, eles delimitarão o perfil de candidato que é considerado alinhado àquela função, indicando as competências transversais e os requisitos mandatórios, de acordo com os padrões mínimos dispostos previamente nos documentos de descrição do cargo.

Deste modo, no mínimo cinco atividades essenciais serão indicadas para serem desempenhadas por aquele candidato, além do curso de preferência para a contratação. Haverá também a delimitação do perfil comportamental requerido pela posição, abordando o tipo de jornada de trabalho e a remuneração. 
Similar ao formulário de requisição de pessoal, o documento de descrição de cargo discrimina as atribuições essenciais que deverão ser cumpridas por aquele colaborador. Serão indicados os requisitos mandatórios exigidos para que ele esteja apto a assumir tal posição, salientando-se a preferência de formação acadêmica, o tempo mínimo de experiência profissional e as competências funcionais, transversais e organizacionais que lhes são inerentes.

Esse relacionamento estreito com os requisitos mandatórios e descrições de cargo configura uma visão arriscada por parte dos profissionais de $\mathrm{RH}$, pois, ao utilizarem a descrição de cargo para predispor sobre o que o colaborador deverá fazer, eles podem considerar que o ambiente organizacional é estático, o que não condiz com a realidade dinâmica dos negócios. Dessa forma, um cuidado a se pensar deve ser evitar estimular apenas ações de controle por parte da empresa, e não ações de desenvolvimento, como diziam Dutra et al. (2008), a fim de afastar a possibilidade de revestir de modernismo uma prática retrógrada.

A aprovação está voltada às necessidades da área solicitante e ao que o candidato oferece, afirmam as entrevistadas. Elas esclarecem que ele deverá apresentar competências técnicas e comportamentais relacionadas ao bom desempenho da função específica, considerando-se que cada área da empresa possui um nível e uma gama de competências diferentes. A analista sênior de $\mathrm{RH}$ observa que, além do que tange à competência em conceito amplo, aplica-se um conjunto de competências organizacionais, mandatórias às posições efetivas, e de comportamentos a elas pertinentes, evidenciando o alinhamento profissional ao perfil requisitado.

Nesse ínterim, consultando a documentação respectiva, pôde-se constatar que a empresa em foco realiza uma divisão entre algumas competências que são exigidas em diversas áreas, classificando-as como transversais, e outras competências que são exigidas apenas por algumas áreas específicas, denominadas funcionais. Ambos os tipos são escalonados em 4 níveis, acompanhando a progressiva capacidade de entrega de resultado por um profissional, onde o nível 1 corresponde às exigências mais básicas e o nível 4 à cobrança mais avançada. Desta maneira, as competências funcionais transversais medirão os níveis de exigência quanto à proficiência de idiomas e ao domínio de informática, como exemplos de competências exigidas de forma crescente, tomando as posições do âmbito corporativo como um todo, ao passo que competências funcionais específicas medirão o conhecimento, a entrega e a habilidade referentes a uma determinada área da empresa. 
Analisando o documento que descreve as competências organizacionais, notase que há competências específicas, que contribuem para a estratégia da empresa, presentes em cargos de gestão e em cargos de staff. Quanto aos primeiros, as competências são a "orientação estratégica", que espera do colaborador a análise de cenários internos e externos, a percepção de tendências e o planejamento estratégico, e a denominada "gestão de pessoas", determinando que o profissional tenha a capacidade de identificar, de desenvolver e de reter o potencial humano.

Já quanto às especificas a cargos de staff, estão a "flexibilidade", que basicamente se refere à adaptação às contingências e aos diversos cenários, a "capacidade analítica", que remete à resolução de problemas e à interpretação e análise das informações, e o "conhecimento técnico", sendo a capacidade de contribuição com a expertise técnica.

Há ainda aquelas designadas tanto aos cargos de staff, quanto aos cargos de gestão, quais sejam: "orientação para resultado", remetendo à capacidade de engajamento com os objetivos e entrega, "relacionamento", que é o saber atuar de forma colaborativa, visando o alcance de resultados coletivos, bem como o "foco em sustentabilidade", que traduz o respeito aos recursos financeiros, ao meio ambiente, à saúde, à segurança e à diversidade.

Analisando criticamente o documento ora mencionado, pode-se inferir que as competências organizacionais da empresa em questão classificam-se estritamente como básicas, pois são importantes para o funcionamento dela, porém não lhe fornecem uma vantagem competitiva, como dizem Prahalad e Hamel (1990) e Brandão (2009). Não foi possível identificar competências organizacionais correspondentes ao conceito de core competencies, ou seja, competências essenciais, que tanto Hitt et al. (1999), quanto Prahalad e Hamel (1990) e Brandão (2009) abordam, afirmando serem espécies de difícil imitação pela concorrência e que, assim, constituem uma vantagem concorrencial. Da mesma forma, não é possível classificálas como firmspecific, conceito que, segundo Dias et al. (2008), remete a competências inerentes ao contexto, às características ou à cultura específicos de uma empresa, dificilmente transferíveis de uma organização a outra.

A conclusão que se obtém da análise do documento pode ser relacionada à divisão que Brandão (2009) propõe em torno das competências individuais, caracterizando-as como técnicas ou como gerenciais, que correspondem aos cargos de staff e de gestão da empresa em voga. Ao levantar várias pautas no que tange a um saber, ou à capacidade de realizar um feito específico, o documento acaba 
fazendo alusão a expressões verbais que caracterizam a noção de competência individual, mencionadas na obra de Fleury e Fleury (2001) e na pesquisa realizada por Sant'anna et al. (2005).

Este último fato comprova a natureza genérica das mesmas e reforça a afirmação de Brandão (2009), de que as competências individuais são mais fáceis de serem observadas e, por isso, mais utilizadas nos processos de gestão por competências. Ainda assim, mesmo diante da predominância das pautas de competências individuais, verifica-se que a empresa também se utiliza daquelas de natureza coletiva, já que nem todas as atividades de trabalho podem ser realizadas de maneira individual, como ressaltado pela obra de Da Silva e Ruas (2016). Um exemplo disso é a competência relatada chamada de "relacionamento" que se trata da exigência de que seus funcionários atuem de forma colaborativa, visando o alcance de resultados coletivos.

Questionada sobre como se deu a definição primária dos requisitos mandatórios e competências, a gerente de $\mathrm{RH}$ esclareceu que, no passado, a área de $\mathrm{RH}$, juntamente com os cargos de liderança na época, elaborou um mapeamento de tais exigências, a fim de identificar a situação da empresa naquele momento quanto a recursos alocados, e a necessidade de recursos externos. Esse procedimento corresponde ao que Brandão (2009) denomina como mapeamento de competências, projeto que criou a base inicial de exigências que norteará os profissionais de $\mathrm{RH}$ em relação ao que buscar em seus candidatos, tendo em vista as estratégias de competitividade da empresa (BRASIL, 2012; GONÇAVES, 2012).

A respectiva base deverá ser atualizada ano após ano, conforme a dinâmica dos negócios, que por vezes altera a estrutura e necessidades da organização. Justamente por tal dinamicidade, a entrevistada frisou que em todo começo de ano fiscal as posições cadastradas e ocupadas passam por validação, processo semelhante ao mapeamento periódico descrito por Brandão (2009).

Por fim, a analista de $\mathrm{RH}$ sênior ressalta que o material oriundo deste mapeamento primário de competências, com as devidas atualizações recorrentes, em conjunto com as documentações descritivas das competências de cada cargo, serve de apoio para a avaliação interna dos profissionais da empresa. Ela explica que as competências organizacionais ali descritas possibilitam o estabelecimento de metas de desempenho, endossando a tese de que a gestão por competências direciona esforços para desenvolver competências fundamentais à obtenção de metas organizacionais (BAHRY, 2005; BRANDÃO, 2009), além de colaborar com a visão 
baseada em recursos (RBV), onde Prahalad e Hamel (1990) afirmam a competência como atributo que permite à organização funcionar e alcançar seus objetivos através dos recursos internos.

Por fim, além de todas as exigências já mencionadas neste tópico, a analista de $\mathrm{RH}$ sênior complementa com a informação de que aprovação de estagiários, além de atrelada às competências e às qualificações que configuram um bom candidato, considera também questões legais específicas, como a disponibilidade a jornadas de 4h a 6h diárias, por exemplo. A profissional explica que em muitas seleções se veem estudantes bastante preparados tecnicamente, vindo de excelentes instituições de ensino, com habilidade de idiomas e de informática, contudo na maioria das vezes o escolhido será o que apresentar maior vontade de aprender e de integrar a companhia.

Tais afirmações parecem se dar pela dificuldade de se encontrar jovens compromissados com o estágio nos dias atuais, que priorizem as atividades a eles delegadas, ainda que essas pareçam simples, como complementa a analista. Neste raciocínio, se percebe que as competências técnicas estão figurando cada vez mais como exigências obrigatórias apenas, fazendo das competências humanas o fator diferencial, que garantirá uma vantagem competitiva àqueles que as tiverem em sua bagagem profissional, conforme Legge (1995) afirma.

\subsubsection{Técnicas de recrutamento e seleção.}

Os tópicos anteriores permitiram concluir que o recrutamento é o processo que delimita o perfil de candidatos que participarão da seleção. A sua importância, segundo Limongi-França e Arellano (2002), reside em definir as necessidades e requisitos da contratação, utilizando-se da triagem curricular para a pesquisa inicial daqueles que atenderão ao cargo.

De fato, a análise dos currículos é essencial, já que é a partir dela que se dá o primeiro contato do $\mathrm{RH}$ com o aspirante à vaga, possibilitando ratificar o interesse dele, checar as informações necessárias e, por fim, convidá-lo à próxima etapa (LIMONGI- FRANÇA; ARELLANO, 2002; ABRAPP, 2015). Ao abordarem tal processo, as entrevistadas explicaram que, após alinhar o perfil requisitado à vaga com o gestor solicitante, o $\mathrm{RH}$ geralmente o divulga no site da Internet vagas.com, recorrendo também a redes sociais, como o Linkedin, ou a indicações que não comprometam as normas éticas da empresa. 
Em seguida, foi relatado que o perfil de cada candidato é confrontado com os parâmetros traçados àquela vaga. Observa-se, inclusive, se as competências técnicas exigidas, a exemplo do conteúdo programático do curso, de possíveis cursos de extensão e das habilidades que configuram as ferramentas primárias à aptidão ao trabalho, conforme ressaltam Storey (1989) e Handel (2003), são devidamente atendidas por ele. Assim, os perfis alinhados são remetidos à aprovação do gestor solicitante, e depois disponibilizados às técnicas de seleção da empresa, que verificará as competências humanas, que representam qualidades subjetivas do profissional em um contexto sensível humano, imerso em condições sociais e organizacionais (STOREY, 1989; HANDEL, 2003).

Após o recrutamento, inicia-se a fase de seleção, como asseveram LimongiFrança e Arellano (2002), momento em que a organização toma as competências como parâmetro para a escolha do candidato mais adequado. Segundo a gerente de $\mathrm{RH}$, a empresa começa promovendo uma dinâmica, quando os candidatos são organizados em torno de uma mesa redonda, onde farão algumas atividades em grupo. Com esta prática, será possível avaliar o desempenho de liderança, como o candidato lida com o social e se ele manifesta cooperação em equipe, competências coletivas que muitas vezes são demandadas pela requisição de pessoal, sendo este, talvez, um dos poucos meios que possibilita a devida identificação delas. A fase culmina numa redação, cuja análise permite avaliar tanto o lado "soff" do candidato, por meio do estudo grafológico que permite inferências sobre a personalidade, quanto o lado "hard", como sua habilidade com a língua portuguesa. Os resultados desse primeiro momento permitem eliminar os perfis menos alinhados, abrindo caminho à fase mais aprofundada, que corresponde às entrevistas individuais.

Além das citadas, o departamento de seleção também se utilizará de outras técnicas, salientam as entrevistadas, a exemplo de testes de atenção concentrada, de personalidade e de raciocínio lógico. Complementam com a aplicação de provas que avaliam proficiência em idiomas e domínio do pacote Office, de provas de conhecimento, responsáveis por avaliar determinados conhecimentos gerais ou específicos da área respectiva, e de provas situacionais, que simulam situações compatíveis com as que o candidato vivenciará na execução do cargo.

A maioria dessas técnicas de seleção é bastante empregada pelos processos seletivos de grandes empresas, segundo predispõe o guia de recrutamento e seleção de pessoal da ABRAPP (2015). Os testes de atenção concentrada, de raciocínio lógico, de idiomas, de pacote Office e de conhecimento específico da área são exemplos de provas que buscam verificar as competências técnicas do candidato. Já 
os testes de personalidade e os testes e atividades situacionais, por outro lado, compreendem as competências humanas do mesmo.

Nesse contexto, uma técnica complementar para avaliar se determinada competência humana está presente é a entrevista por competências, devendo esta ser supervisionada por profissional de nível acima de júnior na empresa em voga. Destaca-se a objetiva observação de fatos concretos e mensuráveis, tais como a observação de conduta pela entrevista comportamental, que permite antever uma ação futura do candidato a partir de sua conduta passada em contexto no qual se faça presente a competência em cheque. Tal ação ratifica a finalidade da seleção por competências como sendo, justamente, a verificação da presença dos comportamentos delimitados como necessários a um cargo e às tarefas dele respectivas (SORANO, 2009; BRASIL, 2012; TRIPATHI, K.; AGRAWAL, M., 2014).

Por fim, consolidando método bastante assertivo e objetivo, destaca-se que a seleção por competências tende a desempenhar alta eficácia na fase de seleção de talentos (BRASIL, 2012; GONÇALVES, 2012), o que parece ser uma das maiores razões que explicam a baixa rotatividade entre os estagiários na empresa, em que a maioria deles costuma cumprir o máximo de dois anos permitido, ou até o período de sua formação, como assevera a coordenadora de $\mathrm{RH}$ da empresa.

\subsubsection{Competências para o trabalho: o Programa de Estágio na empresa estudada}

Quando questionadas acerca da rotina de trabalho a que é submetido o estagiário, as entrevistadas afirmaram a política da empresa em fazer com que o estágio não seja uma transição estática, fornecendo ferramentas para a verdadeira evolução profissional daquele jovem. A exemplo da fala da Gerente Corporativa de RH da empresa, o investimento por parte da empresa faz com que seu programa de estágio fuja da ideia de ajuste qualitativo e quantitativo, utilizada por muitas organizações que veem o estagiário como apenas mais um número a suprir a demanda temporária de mão de obra barata e qualificada, lógica sobre a qual Rocha de Oliveira e Piccinini (2011) dissertam ao analisar o estudo de Domingo (2002).

De fato, pesquisa realizada pela Associação Brasileira de Estágios (2015), confirma a grande competitividade já nessa etapa inicial da vida profissional, quando o índice de 5,8\% aponta o restrito percentual de candidatos que efetivamente conseguem uma vaga de estágio. Diante da grande demanda, a coordenadora de $\mathrm{RH}$ 
afirma que o processo seletivo de estagiários chega a ser mais complexo, com mais etapas, do que os de profissionais efetivos, fato que concorda com a afirmação de Rocha de Oliveira e Piccinini (2011) de que um bom estágio geralmente é precedido de processo seletivo rígido.

Da mesma forma, este resultado reforça o pensamento de Villela e Nascimento (2003), o qual ressalta a adoção de requisitos para recrutamento e seleção semelhantes aos da seleção do quadro efetivo, uma vez que cresce exponencialmente a procura por estágio. A analista de $\mathrm{RH}$ adere ao raciocínio, afirmando o employer branding marcante da empresa, notoriamente um bom lugar para se trabalhar, que atrai facilmente os estagiários, justificando a necessidade de uma peneira mais rígida.

Prosseguindo, a entrevistada esclareceu que cada estagiário é acompanhado diretamente, pelo $\mathrm{RH}$ e pelo gestor da área, por meio de avaliações semestrais, que possibilitam o mútuo aprendizado entre funcionário e empregador. Isso ocorre porque tais avaliações não só mensuram a evolução do estagiário periodicamente, observando a motivação, a satisfação e o nível de produtividade dele, mas também recebem o feedback deste jovem quanto ao programa a que é exposto. Elas são polivalentes em instigar a evolução produtiva, enfatiza a analista, pois na medida em que se vê constantemente avaliado, um estagiário que almeja a efetivação percebe que tem de ir além da entrega de simples resultado esperado, demonstrando interesse contínuo pelo aprendizado e apresentando iniciativa e pró-atividade.

Após a análise da fala da entrevistada, bem como da documentação pertinente às avaliações, sugere-se que a empresa valoriza as competências humanas, explorando a visão "soff", trazida por Storey (1989), ao incentivar a superação da bagagem da formação acadêmica em prol do desempenho de comportamentos que assegurem o verdadeiro diferencial àquele jovem. Nesse sentido, analisando mais intensamente o trabalho do estagiário pela pró-atividade, pela eficácia e pelo interesse contínuo em obter conhecimento, a empresa potencializa as qualidades subjetivas daquele, em detrimento dos profissionais que se restringem à formação técnica (STOREY, 1989). Destacam-se os treinamentos e palestras promovidos pela instituição, abordando temas como Gestão de Carreira, Técnicas de Apresentação e Comportamento, Sustentabilidade, entre outros, dos quais participará o estagiário.

Por fim, o jovem profissional terá o desafio de apresentar seu departamento de trabalho junto a outros estagiários, ao final de cada ano e, segundo a gerente de $\mathrm{RH}$ da empresa, demonstrará uma competência grupal, já que tal ação exige trabalho em equipe e uma organização própria entre eles para que promovam boa apresentação 
frente a pessoas importantes na empresa, inclusive diretores. Verifica-se 0 desenvolvimento de competências coletivas por meio desta ação, nela presentes dois dentre os quatro atributos elencados na tese de Retour e Krohmer (2011), a saber: o referencial comum, que estrutura a ação coletiva, orientando a comunicação entre pessoas do mesmo grupo, e o engajamento subjetivo, que simboliza a mobilização subjetiva das pessoas em prol dos objetivos organizacionais.

O crescimento profissional daquele jovem, segundo Rocha de Oliveira e Piccinini (2011) faz-se notório quando a empresa modula o estágio de modo a exigir o desempenho de tarefas que transcendem 0 habitual exigido pelas outras organizações. Convergindo com este pensamento, a analista de $\mathrm{RH}$ afirma que a companhia instiga os profissionais a desenvolverem competências e conhecimentos que diferem do seu dia a dia, preparando-os para possível efetivação futura, fato que não compactua com a visão generalista de Rocha de Oliveira e Piccinini (2011) sobre o perfil operacional e burocrático das tarefas que são habitualmente designadas pelo mercado aos estagiários, costumeiramente desalinhadas com o curso de graduação.

Neste caso, o programa de estágio desta empresa se aproxima do intuito original do estágio, sendo um ato educativo escolar supervisionado (ROCHA DE OLIVEIRA; PICCININI, 2011), agregando valor ao indivíduo e fazendo com que a área de $\mathrm{RH}$ ganhe cada vez mais espaço organizacional (FLEURY; FLEURY, 2004). 


\section{Conclusão}

O fato que motivou a realização do presente trabalho fora a compreensão do que o mercado de trabalho exige a título de competências em face dos jovens estagiários, profissionais em começo de carreira. Parte-se do pressuposto, apresentado por Villela e Nascimento (2003), de que as competências técnicoinstrumentais típicas dos currículos dos cursos de graduação já não são suficientes por si só, necessitando-se de uma gama de habilidades pessoais e de conhecimentos extracurriculares que assegurarão ao alunado um espaço nas empresas atuais.

Para estudar a problemática apresentada acima, o autor deste trabalho escolheu observar como é a configuração e o tratamento das competências no recrutamento e seleção de uma grande empresa do setor de óleo e gás. Para a realização do estudo, houve uma pesquisa bibliográfica dos mais conceituados teóricos sobre o assunto, com intuito de formar uma base de confrontação para a pesquisa de campo; que por sua vez, se deu por meio de entrevistas com profissionais de recursos humanos da empresa e pesquisa com documentos pertinentes ao $\mathrm{RH}$ da organização estudada. Os dados obtidos pela pesquisa de campo foram submetidos à análise de conteúdo.

Para melhor analisar o tema, dividiu-se a compreensão do termo competências em duas óticas. A Primeira é a de Storey (1989), que o decompõe em duas concepções: competências técnicas e competências humanas. A segunda ótica é apresentada por Dias et al. (2008), classificando as competências em três esferas: as individuais, as coletivas e as organizacionais.

No que concerne à primeira ótica abordada no parágrafo anterior, verificou-se a extrema valorização das competências humanas na empresa estudada, que, segundo Legge (1995) e Storey (1989), asseguram uma vantagem comparativa aos individuos no momento de inserção no mercado, que é tão disputado nos dias atuais. Foi possível constatar claramente a essência de tal afirmação no discurso das entrevistadas, que diversas vezes ressaltaram termos como humildade, comprometimento e pró-atividade. Em congruência com este raciocínio, suas variadas e numerosas técnicas de seleção aplicadas especificamente para verificação das competências humanas remetem ao apreço pelo perfil "soff" (STOREY, 1989) dos candidatos à vaga. Ficou evidente que, cada vez mais, as competências técnicas 
estão se tornando apenas pré-requisitos de nivelamento, ao invés de elementos diferenciais. Em outras palavras, apesar de seu valor, diante das mudanças na dinâmica do mercado, elas deixaram de ter o papel principal na hora da seleção, principalmente quando se trata de jovens profissionais, que costumam ter pouca bagagem técnica.

Abordando a segunda ótica, analisando principalmente os documentos, os resultados mostraram que a empresa valoriza a entrega de resultados para alcançar os objetivos organizacionais. Sendo assim, por meio da analise documental, sugere-se que suas competências organizacionais se classificam como básicas, que conforme Prahalad e Hamel (1990) e Brandão (2009) são importantes para o seu funcionamento, porém não lhe fornecem vantagem competitiva.

Tais competências parecem ser concebidas como competências individuais, relacionadas à capacidade ou à exigência da devida entrega, assim como os documentos descritivos das competências transversais e funcionais fornecidas pela empresa. Apesar de poucas menções, as configurações coletivas estão institucionalizadas em pelo menos uma competência organizacional básica da organização, o que demonstra que as empresas da atualidade pouco a pouco estão buscando formas de introduzi-las no meio empresarial, tendo como contraponto a sua difícil mensuração, fato que foge da pragmática lógica empresarial da atualidade.

Uma das principais limitações do presente estudo foi o pequeno número de entrevistadas, apenas quatro profissionais. Entretanto, somente estas quatro profissionais configuram todas as envolvidas com o recrutamento e a seleção de estagiários, de forma que a seleção de sujeitos da pesquisa abrangeu toda a equipe de $\mathrm{RH}$ da empresa destinada a essa função, atendendo aos objetivos do estudo. Adicionalmente, mesmo tratando-se de uma grande empresa, com bastante tempo de mercado, de estrutura e políticas já definidas e dotada de extensa gama de colaboradores, não se faz possível aplicar os resultados encontrados nesta pesquisa a todas as empresas.

É válido ressaltar que, pelas análises das entrevistas e dos documentos, tornouse viável perceber que a empresa alvo dessa pesquisa emprega um processo seletivo rigoroso e que, na gestão de seus estagiários, segue a lógica original do estágio, salientada por Rocha de Oliveira e Piccinini (2011).

Como esta pesquisa focou apenas na seleção das competências, sugere-se que, para os próximos trabalhos, sejam estudadas outras áreas em que as competências estejam presentes, a exemplo do treinamento e do desenvolvimento, e 
da avaliação de desempenho das mesmas, a fim de complementar as ideias, as críticas e as análises realizadas neste estudo. 


\section{Referências Bibliográficas}

ASSOCIAÇÃO BRASILEIRA DAS ENTIDADES FECHADAS DE PREVIDÊNCIA COMPLEMENTAR (ABRAPP). Guia de Recrutamento e Seleção de Pessoal (2015). Disponível em: <http://sistemas.abrapp.org.br/apoio/guiarecrutamento/guia.pdf>. Acesso em: 29 de set. 2016.

ASSOCIAÇÃO BRASILEIRA DE ESTÁGIOS (ABRES). Estatísticas. Disponível em: <http://www.abres.org.br/v01/dados-estagiarios-estudantes-no-brasil/>. Acesso em: 21 set. 2016.

ASSOCIAÇÃO BRASILEIRA DE RECURSOS HUMANOS (ABRH-RJ), 2015. Os primeiros passos de uma carreira. Disponível em: <http://www.abrhrj.org.br/system/materiais/arquivos/000/000/196/original/boa_chance_ 22_novembro_2015.pdf?1448373579>. Acesso em: 07 out. 2016.

ASSOCIAÇÃO BRASILEIRA DE RECURSOS HUMANOS DO RIO DE JANEIRO $(A B R H), 2016.49 \%$ das empresas têm vagas e não encontram profissionais qualificados. Disponível em: <http://www.abrhbrasil.org.br/cms/materias/noticias/49das-empresas-tem-vagas-e-nao-encontram-profissionais-qualificados/>. Acesso em: 07 out. 2016.

BARDIN, L. Análise de Conteúdo. Lisboa: Edições 70, 1988.

BRANDÃO, H. P. Aprendizagem, contexto, competência e desempenho: um estudo multinível. 2009.

BRANDÃO, H. P.; BAHRY, C. P. Gestão por competências: métodos e técnicas para mapeamento de competências. Revista do Serviço Público, v. 56, n. 2, p. 179-194, 2005.

BRASIL, A. A. Seleção Por Competência. Associação Brasileira de Recursos Humanos do Rio Grande do Sul, 2012.

CARBONE, P. P.; BRANDÃO, H. P.; LEITE, J. B. D. Gestão por competências e gestão do conhecimento. Rio de Janeiro: Fundação Getúlio Vargas, 2005. 
DA SILVA, F. M.; RUAS, R. L. Competências Coletivas: Considerações Acerca de sua Formação e Desenvolvimento. Revista Eletrônica de Administração, v. 22, n. 1, p. 252-278, 2016.

DIAS, G.; BECKER, G.; DUTRA, J.; RUAS, R.; GHEDINE, T. Revisando a noção de competência na produção científica em administração: avanços e limites. In: DUTRA, J.; FLEURY, M. T. e RUAS, R. Competências: conceitos, métodos e experiências. São Paulo: Atlas, 2008.

DRAGANIDIS, F.; MENTZAS, G. Competency based management: a review of systems and approaches. Information Management \& Computer Security, v. 14, n. 1, p. 51-64, 2006.

DURAND, T. L'alchimie de la compétence. Revue Française de Gestion,127 (1), 84-102, 2000.

DUTRA, Joel Souza; FISCHER, André Luiz; RUAS, Roberto de Lima; NAKATA, Lina Eiko. Absorção do conceito de competência em gestão de pessoas: a percepção dos profissionais e as orientações adotadas pelas empresas. In: DUTRA, J; FLEURY, M. T. e RUAS, R. Competências: conceitos, métodos e experiências. São Paulo: Atlas, 2008.

FLEURY, M. T. L.; FLEURY, A. C. C. Alinhando estratégia e competências. Revista de Administração de Empresas, 44(1), 44-57, 2004.

. Construindo o conceito de competência. Revista de administração contemporânea, v. 5, n. SPE, p. 183-196, 2001.

GIL, A. C. Como elaborar projetos de pesquisa - 4. ed. - São Paulo: Atlas, 2002.

GONÇALVES, V. T. Seleção Por Competência. Associação Brasileira de Recursos Humanos do Rio Grande do Sul, 2012.

HITT, M. A.; IRELAND R. D.; HOSKISSON R. E. Strategic Management: Competitiveness and Globalization : Concepts and Cases. Cincinnati, Ohio: SouthWestern College Pub, 1999.

HANDEL, M. J. The Sociology of Organizations. London: Sage Publications, 2003.

LACRUZ, A. J.; VILLELA, L. E. Identidade do Administrador Profissional e a Visão Pós-Industrial de Competência: uma Análise Baseada na Pesquisa 
Nacional sobre o Perfil do Administrador Coordenada pelo Conselho Federal de Administração. Revista de Administração Contemporânea v. 1, n. 2, p. 34-50, 2007.

LEGGE, K. HRM: Rhetoric, Reality and Didden Agendas. In: STOREY, J. Human Resource Management. A Critical Text. London: Thomson Business Press, p.33-59, 1995.

LIMONGI-FRANÇA, A.C.; ARELLANO, E. Os processos de recrutamento e seleção. In: M.T. FLEURY (ed.), As pessoas na organização. São Paulo: Gente, p. 6372, 2002.

MCLUHAN, M. (2011). The Gutenberg galaxy: The making of typographic man. Toronto: University of Toronto Press.

PRAHALAD, C. K.; HAMEL, G. The core competence of the corporation. Harvard Business Review, 68 (3), 79-93, 1990.

RETOUR, D; KROHMER, C. A competência coletiva: uma relação chave na gestão das competências. In: RETOUR, D. et al. Competências coletivas no limiar da estratégia. Porto Alegre: Bookman, 2011.

ROCHA-DE-OLIVEIRA, Sidinei; PICCININI, Valmiria Carolina. Uma análise sobre a inserção profissional de estudantes de administração no Brasil. RAM, Rev. Adm. Mackenzie, São Paulo, v. 13, n. 2, p. 44-75, Abr. 2012

SANT'ANNA, A. S.; MORAES, L. F. R.; KILIMNIK, Z. M. Competências individuais, modernidade organizacional e satisfação no trabalho: um estudo de diagnóstico comparativo. RAE-eletrônica, v. 4, n. 1, art. 1, p. 1-23, 2005.

SORANO, Geraldo Apparecido. Gestão por competências-um estudo de caso na Companhia Brasileira de Alumínio. Revista da Faculdade de Administração e Economia, v. 1, n. 1, p. 30-65, 2009.

SOUZA, Beatriz. Por que é difícil encontrar mão de obra qualificada no país (2013). Disponível em: <http://exame.abril.com.br/economia/noticias/por-que-faltamao-de-obra-qualificada-no-brasil>. Acesso em: 10 de set. 2016.

STOREY, J. Human Resource Management: Still Marching On, or Marching Out. In: STOREY, J., 1989.

TRIPATHI, K.; AGRAWAL, M. Competency Based Management In Organizational. Global Journal of Finance and Management, v. 6, n. 4, p. 349-356, 2014. 
VERGARA, S. C. Projetos e relatórios de pesquisa em administração. 6. ed. São Paulo: Atlas, 2005.

VILLELA, L. E.; NASCIMENTO, L. M. F. do. Competências pós-industriais exigidas pelas empresas a estagiários e recém-formados: pesquisa de campo elaborada junto a sete unidades do Ciee. In: ENANPAD, 27, 2003, Atibaia: Anpad. Atibaia, 2003.

YIN, R. K. Estudo de caso: planejamentos e métodos. Porto Alegre: Bookman, 2005. 


\section{Apêndice 1 - Roteiro de entrevista}

1. O que a EMPRESA valoriza em um estagiário?

2. O que é um bom candidato?

3. O que um candidato precisa ter para ser aprovado? Pode dar um exemplo?

4. O que é competência na sua opinião? (Citar competências apenas se o entrevistado o fizer primeiro) Pode dar um exemplo?

5. Como é o planejamento de $R \& S$ na empresa?

6. Quem planeja e define os pré-requisitos?

7. Como são definidos?

8. Você pode descrever o processo de recrutamento de estagiários?

9. Você pode descrever o processo de seleção de estagiários?

10. Quais são os pontos fortes do processo de Recrutamento?

11. Quais são os pontos fortes do processo de Seleção?

12. Como é a interação com a área solicitante?

13. Que técnicas/meios/fontes são usadas para recrutar?

14. E para selecionar?

15. Pode contar um exemplo de um processo seletivo feito para estagiários?

16. Existe um planejamento para efetivação de estagiários?

17. O que é levado em conta na decisão de efetivar um estagiário? 